\title{
Dust Concentration in Air during the MDF Boards and Polystyrene Milling Operations on CNC Milling Machine
}

Pavel Kic, Miroslav Müller

Faculty of Engineering, Czech University of Life Sciences Prague. Czech Republic. E-mail: kic@tt.czu.cz, muller@tf.czu.cz

\begin{abstract}
During the material milling an amount of dust which can significantly influence surroundings is generated. Mainly workers are exposed to a dust pollution. The aim of this paper is to present results of a microclimatic research focused on the dust pollution in a workshop during the milling of MDF boards (Medium Density Fibreboards) and Polystyrene workpieces on CNC milling machine. The concentration of air dust was measured by the DustTRAK II Model 8530 aerosol monitor. Using the special impactors the $\mathbf{P M}_{1}, \mathbf{P M}_{2.5}, \mathbf{P M}_{4}, \mathbf{P M}_{10}$ size fractions were also measured. Obtained results of measurements and concentrations of different size of dust particles were analysed. The conclusion of the research is that it is necessary to watch the optimization of the milling process as well as secondary effects of the technological operations and the inner environment of workshops which can be contaminated by dust particles. A natural ventilation of the large space in which the CNC milling machine is installed is not sufficient. A recommendable solution for an improvement of the current situation is the installation of a local exhausting equipment.
\end{abstract}

Keywords: Dust fractions, Manipulation, Natural ventilation, Workshop

\section{Introduction}

An industrial production as well as a prototype production require milling of various kinds of materials. The use of non-metallic materials which are parts of larger units is very common. An accuracy of all components, as well as a surface finish, is important. The final adjustment belongs among basic factors influencing the practical application at the milling $[1,2]$. The resultant optimization of the milling process which influences not only a production tact, a price, but also a quality of the functional surface, is the significant factor. Many scientific studies deal with these factors $[3,4,5,6,7,8,9,10]$. The use of $\mathrm{CNC}$ milling machines is advantageous for processing and manufacturing of complicated parts. Relatively lightweight milling materials characterized by a low density cause a formation and a release of considerable amounts of dust particles due to their structure. These particles in the form of dust can significantly influence surroundings, but mainly workers are exposed to the dust pollution. Contaminants generated from milling may consist of the base material being worked and abrasives or materials from the tool. Many modern materials are used in machine and building constructions because they are prospective materials to which a huge attention has been paid during last decades, namely in terms of the machining and of their modifications influencing not only mechanical properties, but also possibilities of further processing, i.e. milling $[5,7,11]$.

However, the problem remains that there is the considerable amount of dust produced during processing, so great attention must be paid to an air purity. The main components from which the MDF boards are processed are different types of wood. Therefore, the attention should be paid to dust mainly from the point of view of wood particulate matter. Wood dust is consistently high in the top 10 causes of occupational asthma in the United
Kingdom. An exposure to inhalable wood dust and compliance with the British Control of Substances Hazardous to Health (COSHH) Regulations 1999 were assessed at a representative cross section of the British woodworking industry [12]. A failure to control the exposure to wood dust adequately could also be partly the result of not recognizing the risks to health. Stakeholders, such as enforcing authorities, insurance companies, trade unions and trades associations each have a role in raising awareness of these issues, in promoting good practice and in improving standards of protection against wood dust.

Various types of wood have been tested for dust generation during various technological operations by researchers during previous years. A content of respirable and inhalable fractions in dust created while sawing beech wood and its modifications is studied in [13]. The particle-size distribution of dust created during different technological operations is a topic of several papers. E.g. the particle-size distribution of dust created during sanding the modified ash wood is in [14], a correlation between the wood cutting parameters and the distribution of the wood particles is published in [15]. The article [16] describes results of the particle size distribution of dust created during a plywood production.

Technological methods, operations and tools used in the processing are also very important. A difference in the mass concentration of airborne dust during circular sawing of six wood-based materials was tested and results are published in [17]. Six wood-based materials: solid sugi (Cryptomeria japonica), lumber, tropical hardwood plywood, softwood plywood, particleboard, and MDF. The mass concentration for all six wood-based materials increased with the revolution speed of the circular saw. The paper [18] describes the results of the particle-size distribution of dust created at the milling of selected wood composites, which was performed using a computer numerical control (CNC) machine. The particle size of the 
dust is subject to the influence of the type of wood composite and the fragmentation degree of wood from which the composites are made. The dust created at milling of fibreboards is characterized by the highest content of the finest particles. It is also 2-3 times higher than in dust from drilling. The paper [19] presents the results of research on the properties of waste chips generated at the manufacturing of windows. It was ascertained that the properties of pinewood waste are different depending on the type of technological operation. On the other hand, the same technological operations for other than pine wood species (oak, meranti) are the source of finer chips with higher bulk density.

The air pollutants released during the laser cutting process of some plastics material, and in particular in relation to the real operations which occur in a factory is the topic of [20]. The air pollution around an expanded polystyrene material manufacturing plant is presented in [21].

The aim of this paper is to present results of the microclimatic research focused on dust pollution in the workshop during the milling of MDF boards (Medium Density Fibreboards) and polystyrene workpieces. The machinery selected for this research includes the classical $\mathrm{CNC}$ milling machine. The secondary aim of this research is to verify possibilities of dust concentration measuring at the milling/cutting of composite materials which are produced on the basis of prototype, such as e.g. biological polymeric composites developed within the research at Department of Material Science and Manufacturing
Technology, Faculty of Engineering in the Czech University of Life Sciences Prague. Therefore the measuring was verified at the classical materials - MDF boards and polystyrene.

\section{Material and Methods}

This research work and measurements were performed in the workshop at the Faculty of Engineering, Czech University of Life Sciences Prague. Specifically it was the workshop of students of Faculty of Engineering preparing a student formula. The workshop has the following dimensions: floor area about $260 \mathrm{~m}^{2}$ and average height $6.5 \mathrm{~m}$, volume approximately $1,690 \mathrm{~m}^{3}$ (verified by the laser distance meter Leica DISTO ${ }^{\mathrm{TM}} \mathrm{D} 3$ ) and it is used mainly for different study and research activities specialised on engineering problems and a technology. It has only natural ventilation by opened doors and windows.

During milling (Fig. 1), the concentration of dust was measured simultaneously in the environment of the workshop near the milling machine CNC: STYLE - BM 6 113 (STYLE Nijverheidsweg 15; 3751 LP Bunschoten; Holland). The milling parameters at measuring the dust particles were following:

- $\quad M D F$ boards - the cutting depth $1 \mathrm{~mm}$, the cutting speed 2,000 m.min ${ }^{-1}$ 4,000 rev. $\mathrm{min}^{-1}$

- Polystyrene - the cutting depth $16.5 \mathrm{~mm}$, the cutting speed 2,000 m.min ${ }^{-1}$; 4,000 rev. $\mathrm{min}^{-1}$

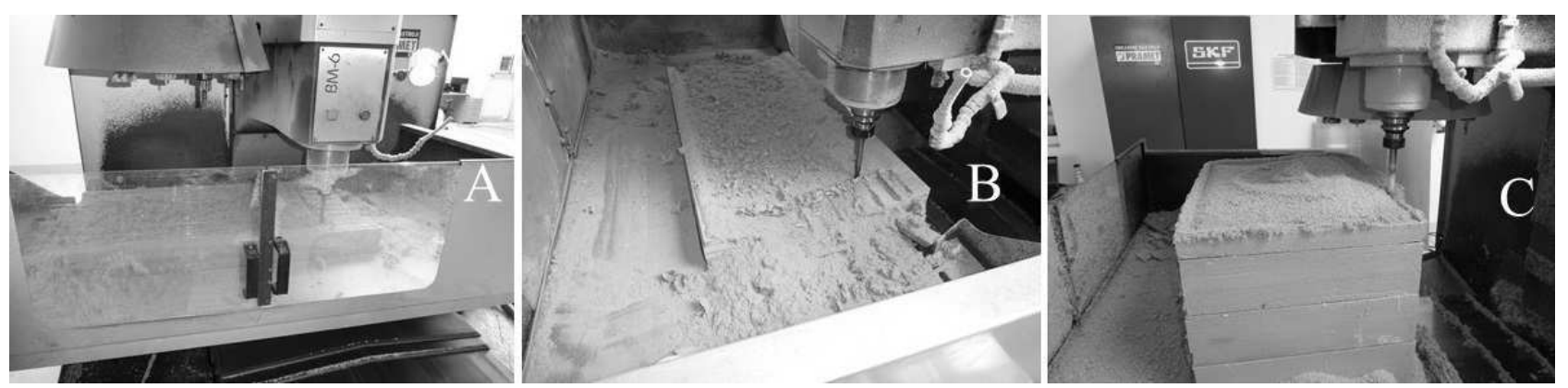

Fig. 1 Measurement of milling: A: MDF, B: detail view on MDF milling, C: Polystyrene

At first, the concentration of dust was measured during milling of MDF boards. Subsequently (another day), it was measured during milling of polystyrene.

According to Act Government Regulation No. 361/2007 Coll. (Act No. 262/2006 Coll.) [22] the dust (based on wood) is characterised as a dust predominantly with irritating effect. For this type of dust from hard (carcinogenic and sensitizing) wood the prescribed Permissible Exposure Limit (PEL) is 2,000 $\mu \mathrm{g} . \mathrm{m}^{-3}$ and for the dust from other (non-carcinogenic and non-sensitizing) wood species 5,000 $\mu \mathrm{g} \cdot \mathrm{m}^{-3}$. PEL for the dust from polystyrene is also $5,000 \mu \mathrm{g} . \mathrm{m}^{-3}$.

Mentioned PEL is rather high, therefore the limit level of outdoor dust can be also used as a criterion for a comparative evaluation of the measured values. According to the Air Protection Act No. 201/2012 PM $_{10}$ limit value in 24 hours is $50 \mu \mathrm{g} . \mathrm{m}^{-3}, 1$ year limit value is $40 \mu \mathrm{g} . \mathrm{m}^{-3}$ and 1 year limit value $\mathrm{PM}_{2.5}$ is $25 \mu \mathrm{g} . \mathrm{m}^{-3}$.

In the frame of this research, the concentration of air dust was measured by the exact instrument DustTRAK II Model 8530 aerosol monitor (Fig. 1). Using the special impactors the $\mathrm{PM}_{1}, \mathrm{PM}_{2.5}, \mathrm{PM}_{4}, \mathrm{PM}_{10}$ size fractions were also measured.

The 90 data of dust concentration for total dust as well as of each fraction size during each measured working activity were collected in the representative place, which can be used for measurement without technological problems. The position of the measuring instrument was at $115 \mathrm{~cm}$ above the floor.

The obtained results of dust measurements were processed by Excel software and verified by statistical software Statistica 12 (ANOVA and TUKEY HSD Test). Different superscript letters $(\mathrm{a}, \mathrm{b})$ mean values in common are significantly different from each other in the rows of the (ANOVA; Tukey HSD Test; $p \leq 0.05)$, e.g. if there are the same superscript letters in all columns of the row it means the differences between the values are not statistically significant at the significance level of 0.05 . 


\section{Results and discussion}

Principal results of dust measurement are summarized and presented in the Table 1 and Fig. 2 - 3. The results indicate that the PEL value of 2,000 $\mu \mathrm{g} \cdot \mathrm{m}^{-3}$ for MDF boards or the PEL value of $5,000 \mu \mathrm{g} . \mathrm{m}^{-3}$ for polystyrene have never been exceeded.

Tab. 1 Total dust concentration and concentration of dust fractions $P M_{10}, P M_{4}, P M_{2.5}$ and $P M_{1}$ in workshop during different operations (milling of MDF boards and polystyrene workpieces). Different superscript letters $(a, b)$ are sign of high significant difference (ANOVA; Tukey HSD Test; $P \leq 0.05$ )

\begin{tabular}{|c|c|c|}
\hline \multirow{2}{*}{ Dust concentration } & MDF boards & Polystyrene workpieces \\
\hline & $\mu g \cdot m^{-3} \pm S D$ & $\mu \mathrm{g} \cdot \mathrm{m}^{-3} \pm \mathrm{SD}$ \\
\hline Total & $68.4 \pm 8^{a}$ & $61.1 \pm 4.3^{b}$ \\
\hline $\mathbf{P M}_{10}$ & $60.5 \pm 2.9^{\mathrm{a}}$ & $59.6 \pm 3.3^{\mathrm{a}}$ \\
\hline $\mathbf{P M}_{4}$ & $56.3 \pm 1.0^{\mathrm{a}}$ & $55.4 \pm 3.6^{b}$ \\
\hline $\mathbf{P M}_{2.5}$ & $55.9 \pm 1.7^{\mathrm{a}}$ & $50.3 \pm 0.9^{b}$ \\
\hline $\mathbf{P M}_{1}$ & $48.9 \pm 0.7^{\mathrm{a}}$ & $42.6 \pm 0.8^{b}$ \\
\hline
\end{tabular}

\section{SD - Standard deviation}

The measurements in the workshop (Table 1) show that total dust concentrations and also concentrations of size fractions $\mathrm{PM}_{10}$ and $\mathrm{PM}_{4}$ during both milling operations were higher than $50 \mu \mathrm{g} . \mathrm{m}^{-3}$, and also limit value $\mathrm{PM}_{2.5} 25 \mu \mathrm{g} . \mathrm{m}^{-3}$ has been exceeded in both milling operations. The concentration of total dust pollution and dust fractions $\mathrm{PM}_{4}, \mathrm{PM}_{2.5}$ and $\mathrm{PM}_{1}$ during milling of $\mathrm{MDF}$ boards were statistically significantly higher than dust levels during the milling of polystyrene workpieces. The dust fraction $\mathrm{PM}_{10}$ was also slightly higher during the milling of MDF boards than $\mathrm{PM}_{10}$ dust level during the milling of polystyrene workpieces but this difference was not statistically significant.

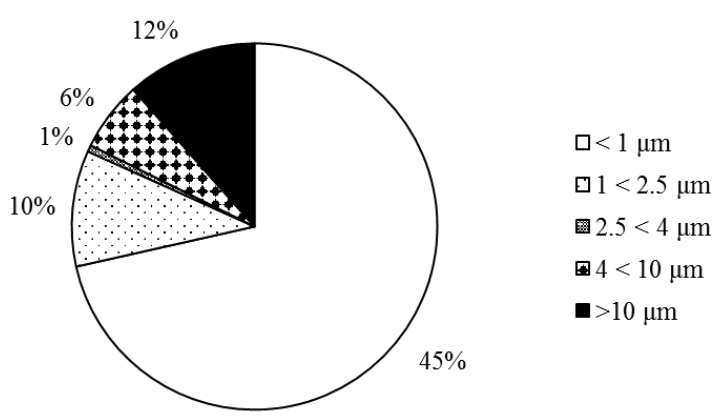

Fig. 2 Percentage of dust fractions in workshop during milling operations of MDF boards

Fig. 2 and Fig. 3 present graphs of the size distribution of dust particles in the workshop air during milling of tested materials. The main part of dust particles $(45 \%$ in the case of MDF boards and $70 \%$ in the case of polystyrene milling) create the smallest particle (smaller than 1 $\mu \mathrm{m})$. The biggest particles over $1 \mu \mathrm{m}$ create only $12 \%$ in the case of MDF boards and $2 \%$ in the case of polystyrene milling. The rest of dust particles is more or less uniformly distributed between the $\mathrm{PM}_{2,5}, \mathrm{PM}_{4}$ and $\mathrm{PM}_{10}$.

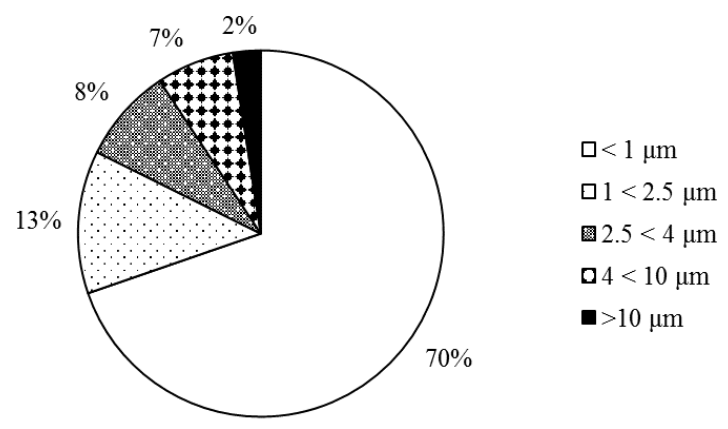

Fig. 3 Percentage of dust fractions in workshop during milling operations of polystyrene workpieces

Chips (fig. 4 A, B, C), which were analysed by SEM Mira 3, came into being at the milling process. It is obvious from the figure that they were both very small and large chips. Dust microparticles emitted to the environment are visible from fig. $4 \mathrm{D}, \mathrm{E}$ and F. Hromasová et al. point out in their research on a necessity and effectiveness of the analysis of the dust microparticles shape by means of SEM [23].

The research proved that it is necessary to observe both the optimization of the milling process which belongs among essential technological parameters, such as it is presented in many research studies, but also secondary effects of given technological operation $[4,5]$. However, it is necessary to focus also on the observation of inner environment of workshops which is influenced by technological operations of single manufacturing companies and it came to their contamination. A significant pollution of the environment is not only by chemical substances, e.g. at the production of adhesive bonds, but also by dust particles which come into being at the milling process and subsequent manipulation with the waste, i.e. the chips $[9,24]$. 

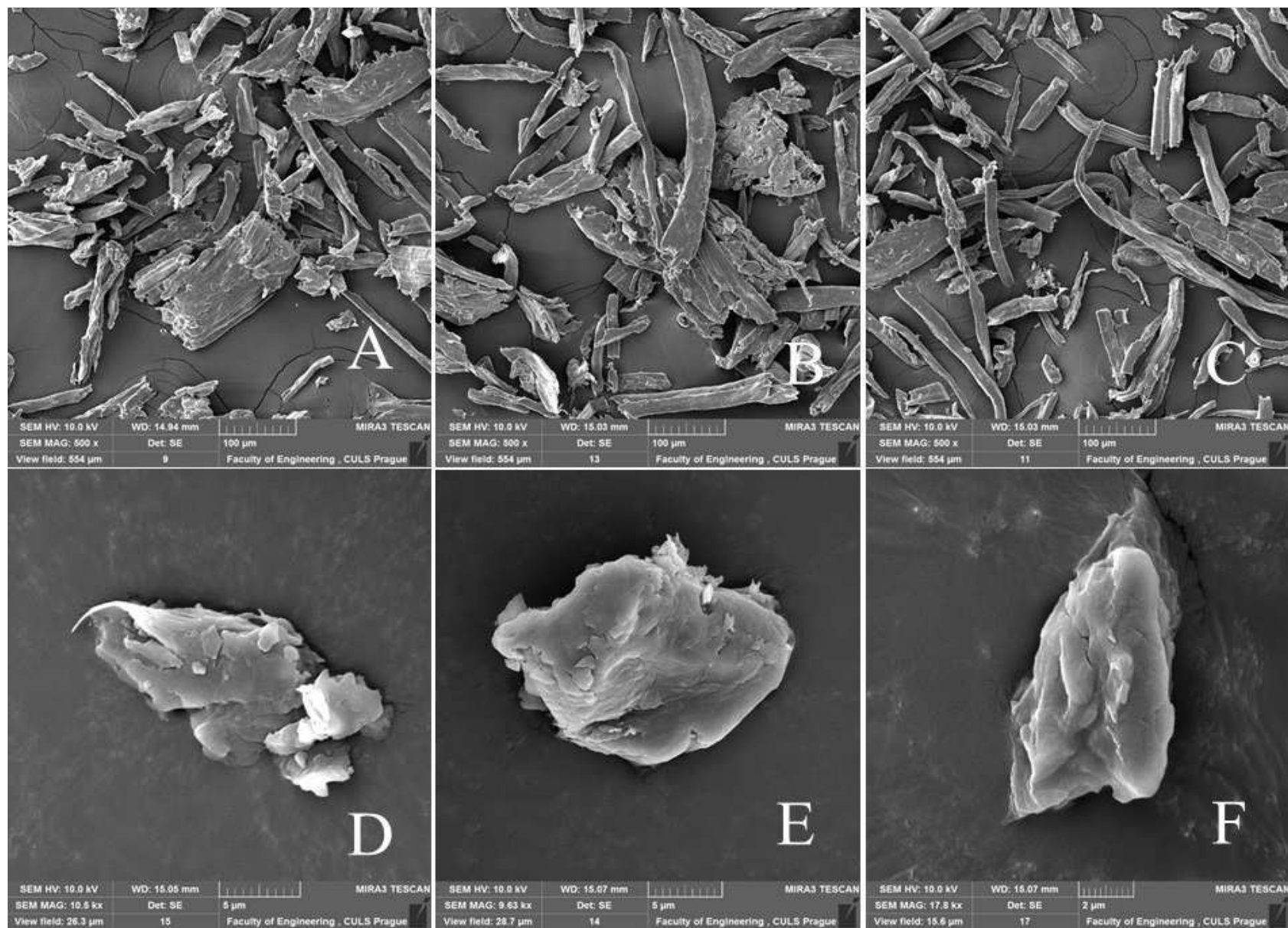

Fig. 4 SEM images of chips from milling process of MDF boards (10 kV, SE detector, WD ca. $15 \mathrm{~mm})-A, B, C 500 x$ $M A G, S E M$ images of dust particles emitted to environment at milling process of MDF boards (10 kV, SE detector, WD ca. $15 \mathrm{~mm}$ ) - D $10.5 \mathrm{kx} M A G, E 9.63 \mathrm{kx} M A G, F 17.8 \mathrm{kx} M A G$

\section{Conclusions}

Measured dust results indicate that the milling of MDF boards and polystyrene workpieces increase the total dustiness around the machine over the limit value 50 $\mu \mathrm{g} . \mathrm{m}^{-3}$, and also limit value $\mathrm{PM}_{2.5}\left(25 \mu \mathrm{g} . \mathrm{m}^{-3}\right)$ has been exceeded. Dust pollution during the milling of MDF boards was higher than milling of polystyrene. The concentration of total dust pollution and dust fractions $\mathrm{PM}_{4}$, $\mathrm{PM}_{2.5}$ and $\mathrm{PM}_{1}$ during milling of MDF boards were statistically significantly higher. The dust fraction $\mathrm{PM}_{10}$ was also slightly higher during the milling of MDF boards but this difference was not statistically significant. Information and data about the size of dust particles are important for the selection of a suitable filter.

The natural ventilation of the large space in which the CNC milling machine is installed is not sufficient. The recommendable solution for improvement of the current situation is the installation of local exhausting equipment. Tested milling machine is not a typical woodworking machine and the use of this CNC machine is only occasional. The machine operator is usually present near to the machine only at the time of adjustment and programming of the machine, the immediate installation of the suction device in this case is not therefore inevitable and it can be prepared for the future improvement of the workshop. However, this pollution could be significant from the point of view of other workers and student present in the hall, but they are usually far away from the machine and near to opened windows or even large outside doors.

The obtained results of this research are important mainly for the use of this type of milling machines in the industrial and other production conditions, where the milling operations are continuously functioning in the spaces with many installed machine tools.

\section{Acknowledgement}

Supported by Internal grant agency of Faculty of Engineering, Czech University of Life Sciences Prague (2016:31140/1312/313109 and 2018:31140/1312/3112).

\section{References}

[1] ALES, Z., PAVlU, J., MULLER, M., SVOBODOVA, J., LEBEDEV, A., YUROV, A., PEXA, M., LINDA, M. (2016). Influence of abrasive - free ultrasonic finishing process of steel on wear. In: Manufacturing Technology, Vol. 16, pp. 4-12.

[2] KUSMIERCZAK, S., MULLER, M., LEBEDEV, A. (2017). Evaluation of aluminium alloy surface machined by means of abrasive-free ultrasonic finishing. In.: Engineering for Rural Development. Jelgava, Latvia University of Agriculture, pp. 167-174. 
[3] MULlER, M., LEBEDEV, A., SVOBODOVA, J., NAPRSTKOVA, N., LEBEDEV, P. (2014). Abrasive-free ultrasonic finishing of metals. In: Manufacturing Technology. Vol. 14, pp. 366-370.

[4] NAPRSTKOVA, N., KALINCOVA, D. (2015). Influence of additional chemical components on milling properties of selected aluminium - silicon alloy. In: Engineering for rural development. Jelgava, Latvia University of Agriculture, pp 766771.

[5] NOVAK, M. (2012): Surfaces with high precision of roughness after grinding. In: Manufacturing technology. Vol. 12, pp. 66 -70.

[6] BROŽEK, M. (2005). Cutting conditions optimization when turning overlays. Journal of Materials Processing Technology. 168, 3, 488-495.

[7] NOVÁK, M. (2011). Surface quality of hardened steels after grinding. In: Manufacturing technology. Vol. 11, pp.55-59.

[8] HOLESOVSKY, F., NAPRSTKOVA, N., NOVAK, M. (2012). GICS for grinding process optimization. In: Manufacturing technology. Vol. 12, pp. 22-26.

[9] KROLCZYK, G., LEGUTKO, S. (2013). The machinability of duplex stainless steel-solutions in practice. In: Manufacturing technology. Vol. 13, pp. 473-478.

[10] HOLESOVSKY, F., NOVAK, M., LATTER, M., VYSLOUZIL, T. (2013). Milling and its influence to surface quality of machine parts. In: Key Engineering Materials. Vol. 581. pp. 354-359.

[11] MICHNA, S., NAPRSTKOVA, N. (2012): The use of fractography in the analysis of cracking after formed workpiece blank mechanical milling from the AlCuSnBi alloy. In: Manufacturing technology. Vol. 12, pp. 174 - 178.

[12] BLACK, N., DILWORTH, M., SUMMERS, N. (2007): Occupational exposure to wood dust in the British woodworking industry in 1999/2000. In: Ann. Occup. Hyg., Vol. 51, pp. 249-260.

[13] HLASKOVA, L., ROGOZINSKI, T., DOLNY, S., KOPECKY, Z., JEDINAK, M. (2015): Content of respirable and inhalable fractions in dust created while sawing beech wood and its modifications. In: Drewno. Vol. 58, pp. 135-146.

[14] ROGOZINSKI, T., HLASKOVA, L., WIERUSZEWSKI, M., OCKAJOVA, A. (2015): Particle-size distribution of dust created during sanding the modified ash wood. In: Annals of Warsaw University of Life Sciences - SGGW Forestry and Wood Technology. No 90, pp. 162-166.
[15] REISZ, L., MAGOSS, E. (2012): Correlation between the wood cutting parameters and the distribution of the wood particles. In: International Scientific Conference on Sustainable Development \& Ecological Footprint. Sopron, Hungary, 5 p.

[16] ROGOZINSKI, T., TROFIMOV, S. (2017): Dust creation during birch plywood production. In: $A n-$ nals of Warsaw University of Life Sciences SGGW Forestry and Wood Technology. No 98, pp. 99-103.

[17] FUJIMOTO, K., TAKANO, T., OKUMURA, S. (2011): Difference in mass concentration of airborne dust during circular sawing of five woodbased materials. In: J. Wood Sci. Vol. 57, pp. 149154.

[18] ROGOZINSKI, T., WILKOWSKI, J., GORSKI, J., SZYMANOWSKI, K., PODZIEWSKI, P., CZARNIAK, P. (2017): Technical note: fine particles content in dust created in CNC milling of selected wood composites. In: Wood and fibre science. Vol. 49, pp. 461-469.

[19] ROGOZINSKI, T., DEMBINSKI, C., OCKAJOVA, A., POTOK, Z. (2017): A study on properties of wood dust created during windows manufacturing. In: Annals of Warsaw University of Life Sciences - SGGW Forestry and Wood Technology. No 98, pp. 94-98.

[20] CHAN, Y.J., YUAN, T.H., TSAI, Y.H., LIN, T.C. (2017): Characterization of endocrine disruptors and particulate matter emissions from laser cutting of plastic film in the TFT-LCD industry. In: Aerosol and Air Quality Research, Vol. 17, pp. 14391449.

[21] ZHU, H., ZHANG, K., SUN, H., WANG, F., YAO, Y. (2017): Spatial and temporal distributions of hexabromocyclododecanes in the vicinity of an expanded polystyrene material manufacturing plant in Tianjin, China. In: Environmental Pollution. Vol. 222, pp. 338-347.

[22] Act No. 262/2006 Coll. Government Regulation No. 361/2007 Coll. Laying down the conditions for the protection of health at work. Changes: 9/2013 Coll. 48 pp. (in Czech).

[23] HROMASOVA, M., KIC, P., MULlER, M., LINDA, M. (2017). Evaluation of quality and efficiency of ventilation equipment by scanning electron microscopy. Agronomy Research. Vol. 15 , pp. $1014-1023$.

[24] KIC, P., MULLER, M. (2017): Dust concentration in air during the aluminium alloy $\mathrm{AlCu} 4 \mathrm{Mg}$ milling operations. In: Manufacturing technology. Vol. 17, pp. 729 - 733. 